\title{
Nutritional and Antioxidant Values of Oyster Mushroom (P. Sajor-caju) Cultivated on Rubber Sawdust
}

\author{
Arini Nuran Mohd Rashidi ${ }^{\#}$ and Tajul Aris Yang ${ }^{\# 1}$ \\ \# Food Technology Division, School of Industrial Technology, Universiti Sains Malaysia, 11800 Pulau Pinang, Malaysia \\ E-mail:taris@usm.my
}

\begin{abstract}
Grey oyster mushroom (Pleurotus sajor-caju) is one of the edible mushrooms from Pleurotus family, which is cultivated commercially in Malaysia. The global mushroom market has shown remarkable growth in recent years and has attractive market potential for the future. This study aimed to determine nutritional value and antioxidant properties of fresh grey oyster mushroom (Pleurotus sajor-caju) with the intention to give better information on nutritional composition of fresh oyster mushroom cultivated on rubber sawdust. Grey oyster mushrooms were freshly harvested from Teloi Agro Farm, Kedah, Malaysia. The proximate analysis was used to determine nutrient composition of grey oyster mushroom. Highest nutritional value of grey oyster mushroom is the moisture content $(90.10 \pm 0.09 \%)$, followed by crude fibre content $(17.27 \pm 1.08 \%)$, protein content $(4.00 \pm 0.31 \%)$, carbohydrates content $(3.54 \pm 0.09 \%)$, while the lowest nutritional value was possessed by fat content $(1.18 \pm 0.33 \%)$ and ash content $(1.16 \pm 0.02 \%)$. The antioxidant activities of the mushroom were measure using total phenolic content (TPC) by Folin-Ciocalteu reagent method and 2, 2diphenyl-1-picrylhydrazyl radical scavenging (DPPH) assay. The hot water extract showed mushroom powder possessed $2.21 \pm 0.03$ $\mathrm{mg} \mathrm{GAE} / \mathrm{g}$ of dried mushroom powder for total phenolic content and at concentration of $0.1 \mathrm{~g} / \mathrm{ml}$ it can inhibit $89.29 \%$ of $\mathrm{DPPH}$ radicals. By virtue of having high fibre with low fat and high antioxidant activity, grey oyster mushroom can be considered as a functional food, which can provide health benefits.
\end{abstract}

Keywords - P. sajor-caju; grey oyster mushroom; sawdust; antioxidant properties; nutritional value

\section{INTRODUCTION}

Mushroom was said to be first cultivated in China as early as $600 \mathrm{AD}$ [1]. Consumption of mushrooms is growing fast due to its balanced nutritional composition [2]-[4] and will give benefits for health improvement because they are low in calories, sodium, fat and cholesterol but rich in fibre, vitamins and minerals [5]. More than that, oyster mushrooms is capable of handling the problem of protein malnutrition in developing and underdeveloped countries [6].

Grey oyster mushroom is one of the 17 mushroom varieties which can be grown in Malaysia [7]. Their growth is suitable with Asian climate, they can be grown in simple and cheaper production costs [8] make them easily available all around the year. Grey oyster mushroom can be cultivated on wide selection of substrates such as rubber sawdust, paddy straw, wood log and sugar baggase which contain high amount of lignocellulosic material [1]. The total demand for mushrooms in Malaysia is expected to increase from 23, 000 tons per year (2008) to 72,000 tons per year in 2020 [9].

P. sajor-caju also known by its common name as grey oyster mushroom, and this name was obtained for the physical appearance which resembled an oyster shell. It was first isolated from India [10],[11] this strain has been identified to be the best strain for cultivation in tropical and subtropical regions [10]-[13]. In Malaysia, oyster mushroom are usually consumed as soup, grilled or deep fried and it has a great demand as local street food.

Among the three species of mushrooms commercially cultivated in India (Agaricus bisporus, Volvariella volvacea, Pleurotus sajor-caju), P. sajor-caju was said to possess unique nutritional and medicinal values, aroma as well as taste [5]. Antioxidants present in mushrooms are possible to be protective agents to help human body to reduce oxidative damage without any interference [14]. [15] agreed that consumption of plant foods can provides protection against various diseases including cancer and cardio- and cerebrovascular diseases.

In this research, proximate composition and antioxidant properties of $P$. sajor-caju was evaluated to give some contribution on nutritional values information of P.sajorcaju cultivated on rubber sawdust in Malaysia.

\section{Materials AND MEthodS}

Kjeldahl Catalyst Tablet was purchased from Merck (Germany). Whereas 2,2-Diphenyl-1-picrylhydrazyl (DPPH), Folin \& Ciocalteu's phenol reagent was obtained from 
Sigma-Aldrich (St. Louis, MO., USA). Ascorbic acid and gallic acid were procured from R\&M (Essex, UK). Petroleum ether $\left(40-60{ }^{\circ} \mathrm{C}\right)$ was purchased from Fisher Scientific (Dublin, Ireland). All other chemicals and reagents used were analytical grade.

\section{A. Samples}

Oyster mushroom was freshly purchased from Teloi Agro Farm Enterprise, Kedah, Malaysia in the early morning. Sample was stored in ice box to retain its freshness before transported for analysis in the USM.

\section{B. Proximate composition}

Proximate composition was done on moisture, fat, crude fibre and ash [16]. Protein factor used in determining crude protein is 4.8 [17], [18] while carbohydrate was calculated by difference.

\section{Extraction}

Antioxidant extraction was carried out according to [19] with slight modification. $2 \mathrm{~g}$ of ground samples were mixed into $50 \mathrm{ml}$ of hot water and stirred for 15 minutes. Samples were centrifuged at $2000 \mathrm{~g}$ for 15 minutes. Supernatants were collected for analysis.

\section{Radical scavenging activity (RSA) on DPPH}

RSA was determined by using a method proposed by [20]. $0.1 \mathrm{ml}$ of samples extraction was mixed with $2.9 \mathrm{ml}$ of $100 \mu \mathrm{M}$ methanolic DPPH (2,2-diphenyl-1-picrylhydrazyl) and vortex mixed for a minute. Absorbance was read immediately at $517 \mathrm{~nm}$ wavelength with Shimadzu UV-vis spectrophotometry, Japan. Vitamin C (ascorbic acid) was used as standard. Radical scavenging activity (RSA) was calculated using the formula:

$$
\% \operatorname{RSA}=\left[\left(\mathrm{A}_{\mathrm{o}}-\mathrm{A}_{\mathrm{s}}\right) / \mathrm{A}_{\mathrm{o}}\right] \times 100
$$

Where $\mathrm{A}_{\mathrm{o}}$ is the absorbance of $100 \mu \mathrm{M}$ methanolic DPPH only and $\mathrm{A}_{\mathrm{s}}$ is the absorbance of reaction mixture.

\section{E. Total phenolic content}

Folin-phenol method [19] was used to determine total phenolic content in mushroom samples. $100 \mu \mathrm{L}$ of sample aliquot was added into $900 \mu \mathrm{L}$ of distilled water. $1 \mathrm{ml}$ of $1 \mathrm{~N}$ Folin-Ciocalteu's Reagent and $2 \mathrm{ml}$ of $10 \%$ sodium carbonate solution were added and mixed before they were incubated for 1 hour at room temperature. Absorbance was measured at $765 \mathrm{~nm}$ with Shimadzu UV-visible spectrophotometer, Japan.

\section{F. Statistical analysis}

All analyses were carried out in triplicate $(\mathrm{n}=3)$ and were analyzed by using SPSS version 17.0 by one-way ANOVA. All of the statistical was performed at the 0.05 significance level and was presented as mean \pm standard deviation $(\mathrm{M} \pm \mathrm{SD})$.

\section{RESULTS AND DISCUSSIONS}

The results of nutritional value obtained for the study are shown in Table 1. Ash content is recorded at $1.16 \pm 0.02 \%$ whereas moisture is $90.10 \pm 0.09 \%$. Ash content signifies mineral content in mushrooms as has been stated by [21] which was possibly resulted from potassium [22], phosphorus, magnesium [23], calcium, copper, iron and zinc [24]. [25] has studied minerals content of P. sajor-caju were varied if cultivated on different substrate.

$P$. sajor-caju has proven to contains high water percentage when incorporated into chicken patty, it helped to reduce the hardness of chicken patty compared to the nonincorporated one [26].This high percentage of water is depended on several factors such as watering frequency, weather and storage condition thus making them highly perishable vegetables in the market.

TABLE I

PROXIMATE COMPOSITION OF FRESH P. SAJOR-CAJU CULTIVATED ON RUBBER SAWDUST.

\begin{tabular}{|c|c|}
\hline Nutritional Composition & \% Fresh Weight \\
\hline Ash & $1.16 \pm 0.02$ \\
\hline Moisture & $90.10 \pm 0.09$ \\
\hline Proteinnf & $4.00 \pm 0.31$ \\
\hline Fat & $1.18 \pm 0.33$ \\
\hline Crude Fiber & $17.27 \pm 1.08$ \\
\hline Carbohydrated & $3.54 \pm 0.09$ \\
\hline
\end{tabular}

A. $\mathrm{NF}=$ protein factor $4.38 \mathrm{D}=$ Calculated by difference .

Protein content in $P$. sajor-caju is $4.00 \pm 0.31 \%$. Conversion factor of 4.38 [17]-[18] has been used to calculate protein content due to high proportion on nonprotein nitrogen compounds, especially chitin [27]. Research [10] agreed that mushrooms contain high protein content among fruits and vegetables even though the amount is not comparable to fish, eggs, chicken or beef. Protein content in mushrooms varies differently among species, and they are affected by environmental factors and stage of fruiting body maturity [27]. The proteins of mushroom are of high quality and rich in various essential amino acids [5].

Fat content is recorded $1.18 \pm 0.33 \mathrm{~g} / 100 \mathrm{~g}$ fresh mushroom. A study by [21] determined fat content in oyster mushroom at $0.15 \pm 0.02 \mathrm{~g} / 100 \mathrm{~g}$ fresh mushroom which is lower compared to king oyster mushroom and golden needle mushroom and from their study, it was found that both Pleurotus (oyster and king oyster mushrooms) species showed similar nutritional composition except for fat and protein levels. Fat content in different species of mushrooms was ranged from $1.1-8.3 \%$ on a dry weight basis and it is representing all classes of lipid compounds including free fatty acids, monoglycerides, diglycerides, triglycerides, sterols, sterol esters and phospholipids [10].

Carbohydrate in mushroom sample was determined to be $3.54 \pm 0.09 \%$. Carbohydrate act as energy provider and they can be found in digestible and non-digestible form in mushrooms. Mannitol [28], glucose [29] and glycogen [30] are examples of digestible carbohydrate exist in mushrooms 
whereas non-digestible form makes up the large component of total carbohydrates of mushrooms [27].

The DPPH method was used to determine the free radical scavenging activity of Pleurotus sajor-caju. The radical scavenging activity (RSA) of mushroom extracts was tested against the DPPH. The \% RSA for P. sajor-caju are presented in Fig. 1. Antioxidant compounds exist in the sample will transfer electron or hydrogen atom to react with DPPH. The odd electron in the DPPH free radical gives a strong absorption maximum at $517 \mathrm{~nm}$ and is purple in color [31]. Reacted DPPH will turn the color from purple to yellow. RSA of mushroom sample varied from 64.51$89.29 \%$ (fig. 1) and increased with the increase in concentration. At $100 \%$ concentration, it can inhibit $89.29 \%$ DPPH. A study done by [32] proved that P. sajor-caju showed comparatively lower RSA than $P$. eryngii, $P$. djamor and $P$. flabellatus $(67.4-69.67 \%$ at $100 \%$ mycelial extract concentration). However, in this study, the RSA of $P$. sajorcaju is determined to be at higher concentration.

Total phenolic content of mushroom extraction was estimated by Folin-Ciocalteu method and results were expressed as $\mathrm{mg}$ of gallic acid equivalents per gram of mushroom powder. Total phenolic contents was determined at $2.21 \pm 0.03 \mathrm{mg} / \mathrm{g}$ in this study as compared to the other type of mushrooms species such as Agaricus bisporus (0.63 $\mathrm{mg} / \mathrm{g})$, Hypzigus marmoreus (0.67 mg/g), Volvariella volvacea $(0.73 \mathrm{mg} / \mathrm{g})$, Flammulina velutipes $(0.75 \mathrm{mg} / \mathrm{g})$, Pleurotus eryngii $(0.44 \mathrm{mg} / \mathrm{g})$, Pleurotus ostreatus $(0.39$ $\mathrm{mg} / \mathrm{g})$, Lentinula edodes $(0.49 \mathrm{mg} / \mathrm{g})$, Hericium erinaceus $(0.46 \mathrm{mg} / \mathrm{g})$ [33]. These phenolic compounds could be used as an important indicator of antioxidant capacity [32]. Higher antioxidant activity could be exhibited with the presence of the greater numbers of hydroxyl groups in the phenolics [34]. Consumption of Pleurotus sajor-caju can be beneficial for protecting body from harmful free-radicals compounds which can create oxidative damage to the body.

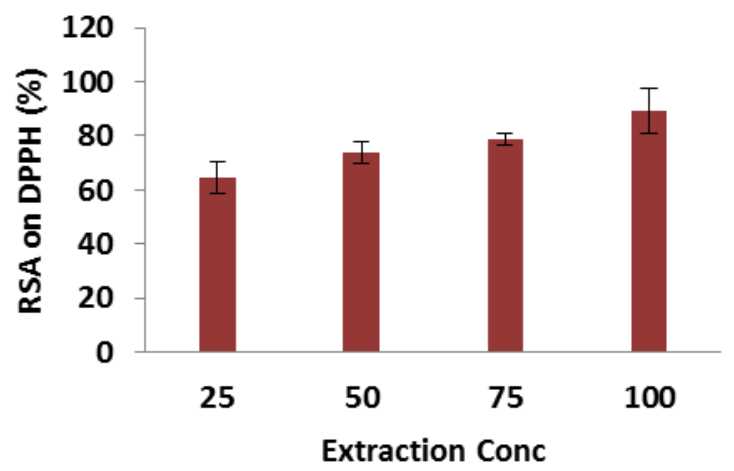

Fig. 1 Radical scavenging activity (\%) of different extraction concentration on DPPH of $P$. sajor-caju cultivated on rubber sawdust.

\section{CONCLUSIONS}

Analyses of the proximate composition of commonly cultivated Pleurotus sajor-caju reveal that they are rich in fibre with low fat and high antioxidant activity. Grey oyster mushroom can be considered as a functional food, which can provide health benefits.

\section{NOMENCLATURE}

DPPH

GAE Gallic acid equivalent

\section{REFERENCES}

[1] T. E. Tisdale, "Cultivation of oyster mushroom on different wood substrate in Hawaii," Master Science thesis, University of Hawaii, USA. 2004.

[2] S.Y. Seo, V.K. Sharma, N. Sharma, "Mushroom tyrosinase: recent prospects." Journal of Agricultural and Food Chemistry, Vol. 51, pp.2837-2853. 2003.

[3] S. Yildiz, U.C. Yildiz, E.D Gezer, A. Temiz, "Some lignocellulosic wastes used as raw material in cultivation of the Pleurotus ostreatus culture mushroom." Process Biochemistry, Vol. 38,pp. 301-306. 2002 .

[4] C. Lee, S. Lee, K.J. Cho, S. Hwang, "Mycelial cultivation of Phellinus linteus using cheese-processing waste and optimization of bioconversion conditions." Biodegradation, Vol. 22, pp.103-110. 2011.

[5] V.J.S. Dunkwal, and S. Singh, "Physico-chemical properties and sensory evaluation of Pleurotus sajor-caju powder as influenced by pre-treatments and drying methods." British Food Journal.Vol. 109: pp.749-759. 2007.

[6] C.K. Chiroro, (2004). MushWorld website. [Online] Available: http://mushroomtime.org/wp-content/uploads/2014/06/02Mushroom-Growers-Handbook-1-Oyster-Mushroom-CultivationMUSHWORLD.pdf]

[7] M.Z. Mat Amin, Y.S. Mohd, A. Harun, "Viability of oyster mushroom industry in peninsular Malaysia." Economic and Technology Management Review. Vol. 8, pp.13-25. 2013.

[8] M. Singh, B. Vijay, S. Kamal, G.C. Wakchaure, "Mushrooms: Cultivation, Marketing and Consumption." Directorate of Mushroom Research, Indian Council of Agricultural Research (ICAR), Solan (India); 2011.

[9] M.T. Haimid, H. Rahim and R. Abu Dardak, "Understanding the mushroom industry and its marketing strategies for fresh produce in Malaysia." Economic and Technology Management Review, 8, 2737. 2013.

[10] S.T Chang and P.G. Miles, Mushrooms: Cultivation, Nutritional Value, Medicinal Effect, and Environmental Effect. 2nd edition. USA: CRC Press, 2004.

[11] C.L. Jandaik, "Artificial cultivation of Pleurotus sajor-caju (Fr.) Singer." Mushroom Journal, Vol.22,pp. 405. 1974.

[12] F. Zadrazil, Cultivation of Pleurotus in the biology and cultivation of edible mushrooms. Chang, S.T. and Hayes, W.A., Eds, New York, USA: Academic Press. 521-557. 1978.

[13] C.P Eugino and N.A Anderson, "The genetics and cultivation of Pleurotus ostreatus.” Mycologia, Vol.60, pp. 627-634. 1968.

[14] A.K Adams and E.O Wermuth, "Antioxidant vitamins and the prevention of coronary heart disease.” Am. Family Physician, Vol.60, pp.895-905. 1999.

[15] B. Halliwell and J.M.C Gutteridge, "Oxygen toxicity, oxygen radicals, transition metals and disease." Biochemical, pp.219-224.

[16] AOAC (Assoc. of analytical Chemistry), (2005). Official Methods of Analysis, 18th ed. Maryland, USA. AOAC International.

[17] P. Manzi, S. Marconi, A. Aguzzi and L. Pizzoferrato, "Commercial mushrooms: nutritional quality and effect of cooking." Food Chemistry, Vol.84, pp. 201-206. 2004.

[18] E.V Crisan and A. Sands, (1978). The biology and cultivation of edible mushroom. Chang and Hayes, Eds. London, England: Acad Press inc. 1978.

[19] N.G Puttaraju, S.U Venkateshaiah, S.M Dharmesh, S.M.N Urs, R. Somasundaram, "Antioxidant activity of indigenous edible mushroom.” Agric. Food Chem., Vol. 54, pp. 9764-9772. 2006.

[20] C. Sanchez-Moreno, J. Larrauri and F. Saura-Calixto, "A procedure to measure the antiradical efficiency of polyphenols." Journal of the Science of Food and Agriculture, Vol. 76, pp.270-276. 1998.

[21] F.S Reis, L. Barros, A. Martins and I.C.F.R Ferreira, "Chemical composition and nutritional value of the most widely appreciated cultivated mushrooms: An inter-species comparative study." Food and Chemical Toxicology, Vol. 50, pp.191-197. 2012. 
[22] P. Mattila, K. Konko, M. Eurola, J.M Pihlava, J. Astola, L. Vahteristo, V. Hietaniemi, J. Kumpulainen, M. Valtonen, and V. Piironen, "Contents of vitamins, mineral elements, and some phenolic compounds in cultivated mushrooms." J. Agric. Food Chem. Vol.49, pp.2343-2348.2001

[23] P. Manzi, L. Gambelli, S. Marconi, V. Vivanti and L. Pizzoferrato,(1999). "Nutrients in edible mushrooms: an interspecies comparative study. "Food Chem. Vol.65, pp. 477-482. 1999.

[24] E. Guillamon, A. Garcia-Lafuente, M. Lozano, M. D’ Arrigo, M.A Rostagno, A. Villares and J.A Martinez, "Edible mushrooms: role in the prevention of cardiovascular diseases." Fitoterapia Vol.81, pp.715-723. 2010.

[25] S. Patrabansh and M. Madan, "Mineral content of the fruiting bodies of Pleurotus sajor-caju single cultivated on different kinds of biomass." Acta Biotechnologiaca 19,Vol. 22, pp.101-109.1999.

[26] W.I Wan Rosli, M.A Solihah, M. Aishah, N.A Nik Fakurudin and S.S.J Mohsin, "Colour, textural properties, cooking characteristics and fibre content of chicken patty added with oyster mushroom (Pleurotus sajor-caju).” International Food Research Journal, Vol.18, pp.621-627. 2011.

[27] X.M Wang, J. Zhang, L.H Wu, Y.L Zhao, T. Li, J.Q Li, Y.Z Wang and H.G Liu, "A mini-review of chemical composition and nutritional value of edible wild-grown mushroom from China." Food Chemistry. Vol.151,pp. 279 - 285. 2014.

[28] J.A Vaz, L.Barros, A. Martins, C. Santos-Buelga, M.H Vasconcelos and I.C.F.R Vasconcelos, "Chemical composition of wild edible mushrooms and antioxidant properties of their water soluble polysaccharidic and ethanolic fractions." Food Chemistry, Vol. 126, pp.610-616. 2011.

[29] M.Y Kim, L.M Chung, S.J Lee, J.K Ahn, E.H Kim, "Comparison of free amino acid, carbohydrates concentrations in Korean edible and medicinal mushrooms." Food Chemistry, Vol.113, pp.386-393. 2009.

[30] V.A Diez and A.Alvarez, "Compositional and nutritional studies on two wild edible mushrooms from northwest Spain." Food Chemistry, Vol.75, pp. 417-422. 2001.

[31] A. Prakash, F. Rigelhof and E. Miller, "Antioxidant activity. In Medallion Laboratories Analytical Progress," Medallion Laboratories, Minneapolis, USA. Pp. 1-4. 2004

[32] K.K Mishra, R.S Pal, R.A Kumar, C. Chandrashekara,S.K Jain,J.C Bhatt, "Antioxidant properties of different edible mushroom species and increased bioconversion efficiency of Pleurotus eryngii using locally available casing materials." Food Chemistry. Vol.138, pp.1557-1563. 2013.

[33] H.Y Fu, D.E Shieh and C.T Ho, "Antioxidant and free radical scavenging activities of edible mushrooms," Journal of Food Lipids, Vol. 9, pp.35-46. 2002

[34] N. Rangkadilok, S. Sitthimonchai, L. Worasuttayangkurn, C. Mahidol, M. Ruchirawat and J. Satayavivad, "Evaluation of free radical scavenging and antityrosinase activities of standardised longan fruit extract." Food and Chemical Toxicology, Vol. 45, pp.328-336. 2007. 